\title{
Pengaruh Pendidikan Kesehatan Terhadap Tingkat Kecemasan Pasien Praoperasi Bedah Mayor Othopedi Di Rsud Dr Soedarso Pontianak
}

\author{
The Effect of Health Education on Anxiety Level of Pre-Operative \\ Patients undergoing the Major Orthopedic Surgery \\ in Dr. Soedarso General Hospital Pontianak \\ Aina Rahayu Dewi*, Yoga Pramana*, Hendra* \\ *Program Studi Keperawatan, Fakultas Kedokteran, Universitas Tanjungpura \\ Jl. Prof. Dr. H. Hadari Nawawi, Pontianak \\ Email: ainarahayudewi@yahoo.com
}

\begin{abstract}
ABSTRAK
Latar Belakang: Pembedahan menimbulkan reaksi emosional bagi klien, seperti kecemasan akan kematian, kecacatan, anastesi, dan rasa takut akan ada muncul komplikasi pasca operasi. Salah satu tindakan untuk mengurangi tingkat kecemasan adalah dengan cara pendidikan kesehatan untuk meningkatkan kesiapan mental pasien.

Tujuan: Menganalisis adanya pengaruh pendidikan kesehatan terhadap tingkat kecemasan pasien praoperasi bedah mayor orthopedi di RSUD Dr. Soedarso Pontianak.

Metode: Penelitian kuantitatif yang menggunakan quasy experiment dengan pre test dan post test nonequivalent control group. Total responden pada kelompok intervensi dan kontrol adalah 26 orang. Tingkat kecemasan diukur menggunakan lembar kuesioner Amsterdam Preoperative Anxiety and Information (APAIS).
\end{abstract}

Hasil: Uji analisis $\mathrm{T}$ berpasangan didapatkan nilai $\mathrm{P}=0.001(\mathrm{p}<0,05)$ yang berarti ada pengaruh pendidikan kesehatan terhadap tingkat kecemasan pasien praoperasi ortopedi.

Kesimpulan: Ada pengaruh pendidikan kesehatan terhadap tingkat kecemasan pasien praoperasi bedah mayor ortopedi. Sehingga, pendidikan kesehatan dapat direkomendasikan untuk menurunkan tingkat kecemasan.

Kata Kunci: pendidikan kesehatan, kecemasan, pasien praoperasi 


\title{
The Effect of Health Education on Anxiety Level of Pre-Operative Patients undergoing the Major Orthopedic Surgery in Dr. Soedarso General Hospital Pontianak
}

\begin{abstract}
S
Background: Surgery may cause emotional reactions on patients, such as anxiety due to fear of death, disability, anesthesia and the post-operative complications. One of measures to reduce the anxiety level is through health education to increase patients' mental preparedness.
\end{abstract}

Aim: To investigate the effect of health education on the anxiety levels in pre-operative patients undergoing the major orthopedic surgery in Dr. Soedarso General Hospital, Pontianak.

Method: This is a quantitative study using quasi experimental design with pre-and posttest method with non-equivalent control group. The number of respondents was 26. The anxiety level was measured by Amsterdam Preoperative Anxiety and Information (APAIS).

Result: The paired t-test shows $p=0.001(p<0.05)$ which means there was an effect of health education on anxiety level of pre operative patients undergoing the major orthopedic patients.

Conclusion: There was an effect of health education on the anxiety levels in preoperative patients undergoing major orthopedic surgery. Therefore, health education can be advised to reduce the anxiety levels.

Keywords: health education, anxiety, pre-operative patients 


\section{PENDAHULUAN}

Keperawatan praoperatif merupakan tahapan awal dari keperawatan perioperatif. Pengkajian secara integral dari fungsi pasien meliputi fungsi fisik, biologis, dan psikologis sangat diperlukan untuk keberhasilan dan kesuksesan suatu operatif. Persiapan mental merupakan hal yang tidak kalah pentingnya dalam proses persiapan operatif karena mental pasien yang tidak siap atau labil dapat berpengaruh terhadap kondisi fisiknya. Tindakan pembedahan merupakan ancaman potensial maupun aktual pada integritas seseorang yang dapat membangkitkan reaksi stres psikologis maupun fisiologis. Fase preoperatif dimulai ketika keputusan untuk intervensi bedah dibuat dan berakhir ketika pasien dikirim ke meja operasi. ${ }^{1}$

The World Bank menyatakan hingga tahun 2015 jumlah tindakan operasi bedah di dunia terjadi sebanyak 4.511.101 per 100.000 populasi dengan benua Australia yang menempati posisi tertinggi sekitar 28.907 per 100.000 populasi. Data dari Wolrd Health Organization (WHO) tahun 2013 jumlah pasien yang mengalami tindakan operasi terus mengalami peningkatan yang sangat signifikan. Tahun 2011 tercatat 140 juta jiwa pasien yang mengalami tindakan operasi di seluruh rumah sakit di dunia. Jumlah ini semakin meningkat pada tahun 2012 sebesar 148 juta jiwa. Kejadian di Indonesia berdasarkan perhitungan data tabulasi Nasional Departemen Kesehatan Republik Indonesia tahun 2009, menyatakan bahwa tindakan bedah menempati urutan ke-11 dengan persentase $12,8 \%$. Sepanjang tahun 2012 menurut data dari Kementrian Kesehatan Republik Indonesia jumlah tindakan operasi menempati angka hingga mencapai 1,2 juta jiwa. Prevalensi bedah mayor tercatat sebanyak 75 kasus yang dilakukan dalam tiga bulan. Lebih dari
$60 \%$ bedah mayor terjadi pada kasus bedah digestif ${ }^{2,14,3}$.

Data World Health Organization (WHO) tahun 2007 menyatakan bahwa $25,1 \%$ atau 8.922 jiwa klien post operasi yang dirawat di unit perawatan intensif mengalami gangguan kejiwaan dan $7 \%$ atau 2.473 orang klien mengalami kecemasan. Hasil penelitian lain di Civil Hospital Karachi, Pakistan, yang dilakukan oleh Masood (2006), mengatakan bahwa $57,65 \%$ pasien praoperasi mengalami kecemasan. Dari penelitian tersebut disimpulkan bahwa sebagian besar pasien praoperasi mengalami kecemasan karena takut dengan pembiusan dan anastesi ${ }^{13}$.

Studi pendahuluan yang dilakukan pada bulan Desember 2018 di RSUD. Dr. Soedarso Pontianak didapatkan jumlah pasien yang menjalani bedah mayor periode Januari hingga November 2018 berjumlah 1.743 jiwa dengan kejadian operasi paling banyak yaitu pada bedah ortopedi. Pada bulan September sampai November 2018 tercatat sebanyak 432 kasus bedah mayor dengan 86 kasus bedah orthopedi, 36 kasus bedah anak, 60 kasus bedah umum, 66 kasus bedah gigi dan mulut, 46 kasus bedah urologi, 46 kasus bedah plastik, 19 kasus bedah THT, 49 kasus bedah mata dan syaraf, dan 23 kasus bedah ginekologi. Dari hasil pengukuran kuisoner APAIS yang dilakukan di ruang bedah kepada 7 pasien yang akan menjalani operasi didapatkan 2 orang dengan kecemasan ringan pada pasien operasi urologi dengan operasi srtriktur urea, 3 orang dengan kecemasan sedang pada pasien yang akan operasi jenis 2 striktur urea dan orif tibia, dan 3 orang dengan kecemasan berat pada pasien cancer mamae, cancer nasofaring, dan fraktur kruris sinistra.

Berdasarkan hasil wawancara dengan salah satu perawat di ruangan bedah RSUD Dr. Soedarso bahwa pada kasus pasien yang mengalami kecemasan dapat diketahui dari tekanan 
darah meningkat, nadi meningkat, dan akral dingin. Perawat biasanya menggunakan teknik relaksasi napas dalam dan distraksi untuk menurunkan kecemasan pasien karena relaksasi napas dalam adalah yang paling mudah dilakukan. Berdasarkan hasil wawancara dengan pasien di ruang bedah RSUD Dr. Soedarso bahwa pasien mengalami kecemasan karena suasana ruangan yang panas dan sempit, pengaruh dari pasien yang postoperasi dalam satu kamar, takut tidak dapat beraktifitas kembali, dan tidak bisa bangun lagi setelah di bius. Berdasarkan hasil wawancara dengan 7 keluarga pasien di ruang rawat inap bedah RSUD Dr. Soedarso bahwa ada pasien yang diserahkan sepenuhnya kepada asisten rumah tangga karena keluarga pasien sedang sibuk bekerja , anak tidak ada mendampingi ketika orang tua mau di operasi dengan alasan sedang bekerja, dan hanya menunggu ketika pulang kerja.

Berdasarkan fenomena di atas peneliti merasa tertarik untuk melakukan penelitian yang berjudul pengaruh pendidikan kesehatan terhadap tingkat kecemasan pada pasien praoperasi bedah mayor orthopedi di ruang rawat inap RSUD Dr. Soedarso Pontianak.

\section{BAHAN DAN METODE}

Jenis penelitian ini adalah penelitian kuantitatif menggunakan desain penelitian quasy experiment dengan jenis pre test and post test nonequivalent control group. ${ }^{4}$ Penelitian ini dilaksanakan di di Ruang Rawat Inap Bedah RSUD Dr. Soedarso Pontianak dan waktu pengumpulan data dimulai pada tanggal tanggal 21 Januari 2019 sampai 13 Mei 2019 yang dilakukan, jumlah responden yang digunakan sebanyak 26 responden. Teknik yang digunakan untuk pengambilan sampel pada penelitian ini adalah non probability sampling dengan menggunakan purposive sampling. ${ }^{10}$
Instrumen yang digunakan pada penelitian ini yaitu lembar kuesioner Amsterdam Pre Operative Anxiety and Information Scale (APAIS), ditambahkan data pendukung yaitu lembar observasi pengukuran tekanan darah, nadi, respirasi, dan suhu tubuh.

Analisis data pada penelitian ini menggunakan analisis statistik komputer. Setelah data terkumpul kemudian dilakukan pengolahan data dengan menggunakan frekuensi untuk analisis univariat, dan analisis bivariat menggunakan uji Paired T-Test untuk melihat pengaruh dari kedua intervensi.

\section{HASIL}

1. Analisis Univariat

Tabel 4.1 Karakteristik Responden Berdasarkan Usia, Jenis Kelamin, Pendidikan, Pekerjaan ( $\mathrm{n}=26$ )

\begin{tabular}{|c|c|c|c|c|}
\hline \multirow[t]{2}{*}{$\begin{array}{l}\text { Karakteristi } \\
\text { k }\end{array}$} & \multicolumn{2}{|c|}{$\begin{array}{l}\text { Interven } \\
\text { si }\end{array}$} & \multicolumn{2}{|c|}{ Kontrol } \\
\hline & $f$ & $\%$ & $F$ & $\%$ \\
\hline Usia & & & & \\
\hline $\begin{array}{l}\text { Remaja } \\
\text { Akhir (15-25 } \\
\text { Tahun) }\end{array}$ & 2 & 15,4 & 4 & $\begin{array}{l}30, \\
8\end{array}$ \\
\hline Dewasa & 3 & 23,1 & 5 & 38 \\
\hline Awal (26-35 & 8 & 61,5 & 4 & 5 \\
\hline Tahun) & & & & 30 \\
\hline Dewasa & & & & 8 \\
\hline Akhir (36-45 & & & & \\
\hline Tahun) & & & & \\
\hline Jenis & & & & \\
\hline Kelamin & & & & \\
\hline Laki-laki & 8 & 61,5 & 7 & $\begin{array}{l}53, \\
8\end{array}$ \\
\hline Perempuan & 5 & 38,5 & 6 & $\begin{array}{l}46, \\
2\end{array}$ \\
\hline
\end{tabular}




\begin{tabular}{|lllll|}
\hline Karakteristi & \multicolumn{2}{l}{$\begin{array}{l}\text { Interven } \\
\text { ki }\end{array}$} & \multicolumn{2}{l|}{ Kontrol } \\
\cline { 2 - 5 } & $\boldsymbol{f}$ & $\mathbf{\%}$ & $\boldsymbol{F}$ & $\mathbf{\%}$ \\
\hline \hline Pendidikan & & & & \\
Tidak & 0 & 0 & 0 & 0 \\
Sekolah & 6 & 46,2 & 2 & 15, \\
SD & 1 & 7,7 & 2 & 4 \\
SMP & 4 & 30,8 & 8 & 15, \\
SMA & & & & 4 \\
& & & & 61, \\
& & & & 5 \\
Perguruan & 2 & 15,4 & 1 & 7,7 \\
Tinggi & & & & \\
Pekerjaan & & & & \\
Bekerja & 1 & 92,3 & 1 & 84, \\
Tidak & 2 & 7,7 & 1 & 6 \\
bekerja & 1 & & 2 & 15, \\
& & & & 4 \\
& & & & \\
\hline
\end{tabular}

Sumber: Data Primer (2019)

Hasil analisis pada tabel 4.1 di atas dapat disimpulkan bahwa pada kelompok intervensi, kategori usia responden sebagian besar pada rentang usia dewasa akhir yaitu (36-45 tahun) dengan persentase $61,5 \%$. Jumlah responden sebagian besar berjenis kelamin laki-laki dengan persentase $61,5 \%$. Kategori pendidikan responden pada kelompok intervensi hampir setengahnya berpendidikan sekolah dasar dengan persentase 46,2\%. Kategori pekerjaan responden pada kelompok intervensi sebagian besar bekerja dengan persentase $92,3 \%$.

Kategori usia responden pada kelompok kontrol hampir setengahnya pada rentang usia lansia awal (26-35 tahun) dengan persentase $38,5 \%$, pada kelompok kontrol sebagian besar berjenis kelamin laki-laki dengan persentase $53,8 \%$. Kategori pendidikan responden pada kelompok kontrol sebagian besar berpendidikan SMA dengan persentase $61,5 \%$ dan kategori pekerjaan responden pada kelompok kontrol sebagian besar bekerja dengan persentase $61,5 \%$.

\section{Analisis Bivariat}

Tabel 4.4 pengaruh pendidikan kesehatan terhadap tingkat kecemasan pasien praoperasi bedah mayor orthopedi.

\begin{tabular}{|lllll|}
\hline $\begin{array}{l}\text { Kelompok } \\
\text { Kecemasa } \\
\text { n }\end{array}$ & $\begin{array}{l}\text { Vari } \\
\text { abel }\end{array}$ & $\begin{array}{l}\text { Me } \\
\text { an }\end{array}$ & SD & P \\
\hline Intervesi & $\begin{array}{l}\text { Pre } \\
\text { test }\end{array}$ & 3,6 & 0,5 & 0,0 \\
& Post & 2,5 & 06 & 01 \\
& test & 4 & 19 & \\
Kontrol & Pre & 3,4 & 0,6 & 0,1 \\
& test & 6 & 60 & 68 \\
& Post & 3,3 & 0,7 & \\
& test & 8 & 68 & \\
\hline
\end{tabular}

Sumber: Uji T Berpasangan (2019)

Tabel 4.4, didapatkan bahwa nilai $p$ tingkat kecemasan pada kelompok intervensi 0,001 dan nilai $\mathrm{p}$ tingkat kecemasan pada kelompok kontrol $0,168$ ( $p>0,05)$. Jadi penelitian ini bermakna ada pengaruh pendidikan kesehatan terhadap tingkat kecemasan praoperasi bedah mayor orthopedi sehingga ho ditolak dan ha diterima.

\section{PEMBAHASAN}

\section{Karakteristik Responden \\ Berdasarkan Usia}

Hasil penelitian yang telah dilakukan oleh peneliti pada 26 responden di ruang rawat inap RSUD Dr. Soedarso Pontianak bahwa seluruh responden berada pada usia produktif yaitu 15-45 tahun dan terdapat 3 kategori usia responden yaitu remaja akhir (15-25 tahun), dewasa awal (26-35 tahun), dan dewasa akhir (36-45 tahun) ${ }^{7}$. Rentang usia dewasa akhir (36-45 tahun) merupakan jumlah usia terbanyak dari semua responden dengan jumlah 12 orang $(46,16 \%)$ dan usia remaja akhir (15-25 tahun) merupakan jumlah usia paling sedikit yaitu sebanyak 6 orang 
$(23,07 \%)$. penelitian ini dikarenakan responden yang mengalami fraktur kebanyakan disebabkan oleh kecelakaan kerja, jatuh, terpeleset, maupun karena kerapuhan tulang yang terlalu besar, dari semua faktor-faktor penyebab tersebut dapat menyebabkan terjadi fraktur.

Penelitian ini usia terbanyak pada rentang dewasa akhir yaitu 36-45 tahun karena di usia ini termasuk usia produktif. Pada usia produktif ini sering mengalami kecemasan karena banyak hal yang dipikirkannya seperti takut tidak bisa beraktivitas kembali setelah di operasi.

Berdasarkan penelitian ini sejalan dengan menurut Ganka (2013) didapatkan bahwa hasil dari 30 responden 17 diantaranya berusia diatas 40 tahun yang paling banyak mengalami kecemasan. Hal ini dikarenakan faktor usia pada pasien praoperasi sangat berpengaruh terhadap kesiapan dalam menghadapi operasi, dimana pada usia tersebut termasuk usia produktif, sehingga individu masih memikirkan hal-hal seperti pekerjaan dan aktivitas sehari-hari.

\section{Karakteristik Responden \\ Berdasarkan Jenis Kelamin}

Hasil penelitian ini berdasarkan karakteristik jenis kelamin menunjukkan bahwa sebagian besar subjek penelitian adalah responden yang memiliki jenis kelamin laki-laki dengan jumlah 15 orang $(57,7 \%)$ dan sisanya jenis kelamin perempuan dengan jumlah 11 orang $(42,3 \%)$. Sebagian besar responden pada penelitian ini memiliki jenis kelamin laki-laki, karena hal ini dipengaruhi populasi laki-laki yang mengalami operasi orthopedi lebih banyak dibandingkan perempuan. Meningkatnya kejadian fraktur pada laki-laki lebih sering daripada perempuan karena laki-laki mengalami aktivitas fisik yang tinggi seperti olahraga, pekerjaan atau luka yang disebabkan tabrakan. Namun untuk tingkat kecemasan sebenarnya tidak berbeda jauh antar laki-laki dan perempuan karena tergantung dari proses koping dan cara adaptasi terhadap stresor yang dimiliki pasien, pasien yang memiliki koping dan tingkat adaptasi yang baik terhadap stresor akan ada timbulnya rasa cemas dalam dirinya sendiri.

Penelitian ini bertolak belakang dengan penelitian Nabhani \& Widyaastuti (2014) yang dilakukan di RSUD Dr. R. Suharno Surakarta tentang gambaran tingkat kecemasan pada pasien praoperasi fraktur femur dengan sampel sebanyak 20 responden yang mengalami kecemasan di antara sebesar $75 \%$ berjenis kelamin laki-laki dan $25 \%$ berjenis kelamin perempuan didapatkan hasil jenis kelamin laki-laki lebih mengalami kecemasan daripada perempuan. Dan tidak sejalan dengan penelitian Davidson, Kendrick \& Frech (2016) dengan jumlah responden sebanyak 121 orang diantaranya berjenis kelamin laki-laki sebesar $62,8 \%$ responden sedangkan $37,2 \%$ responden berjenis kelamin perempuan didapatkan hasil yaitu tidak terdapat perbedaan yang signifikan pada kecemasan antara responden berjenis kelamin laki-laki dan perempuan tetapi dalam hal ini responden laki-laki lebih mengalami kecemasan pada saat pascaoperasi sedangkan perempuan lebih mengalami kecemasan efeknya seperti muntah dan mual sebagai komplikasi pascaoperasi yang lebih memicu kecemasan.

\section{Karakteristik Responden Berdasarkan Pendidikan}

Hasil penelitian ini berdasarkan karakteristik pendidikan responden menunjukkan bahwa tingkat pendidikan responden yang diteliti tidak sekolah, sekolah dasar, sekolah menengah pertama, sekolah menengah atas, perguruan tinggi objek penelitian adalah responden yang terbanyak berpendidikan Sekolah Menengah Atas 
dengan jumlah 12 orang $(46,16 \%)$, pendidikan dapat menjadi salah satu faktor predisposisi timbulnya kecemasan yang berlebih. Semakin tinggi pendidikan seseorang, diharapkan semakin baik pula pengetahuan seseorang tentang kecemasan, sehingga dapat mengetahui risiko dari kecemasan. Akan tetapi pada tingkat perguruan tinggi tidak semua dapat memahami masalah kesehatan

Penelitian sejalan dengan penelitian Ganka (2013) didapatkan bahwa hasil dari 30 responden 17 diantaranya berusia diatas 40 tahun yang paling banyak mengalami kecemasan. Hal ini dikarenakan faktor tingkat pendidikan dasar yang mengalami kecemasan pada pasien praoperasi sangat berpengaruh terhadap keseiapan dalam menghadapi operasi, dimana pada tingkat pendidikan tersebut termasuk pendidikan dasar. Individu tingkat pendidikan dasar sebagian besar sulit untuk memahami penjelasan terlalu banyak, kalau pasien merasa cemas, takut keingintahuan yang mendalam umumnya mereka takut bertanya dan takut jawaban yang diberikan mangkin membuat mereka menjadi cemas sehingga koping terhadap kecemasan nampak secara internal di dalam dirinya. Tingkat pendidikan mempengaruhi proses pemikiran seseorang dalam hal memahami penjelasan serta pengambilan keputusan dan semakin mudah berpikir rasional dan semakin mudah menangkap informasi baru termasuk dalam menguraikan permasalahan baru.

\section{Karakteristik Responden Berdasarkan Pekerjaan}

Penelitian ini juga membahas karakteristik responden berupa pekerjaan, bahwa tingkat pekerjaan responden yang diteliti bekerja dan tidak bekerja objek penelitian adalah responden yang terbanyak bekerja dengan jumlah 8 orang $(61,5 \%)$, pekerjaan dapat menjadi salah satu faktor predisposisi timbulnya kecemasan yang berlebih.

Dari hasil penelitian diatas sejalan dengan penelitian Ganka (2013) menunjukkan bahwa dari 30 responden yang akan menjalani operasi bedah mayor digestif pasien yang mempunyai pekerjaan yang mengalami kecemasan 25 orang. Apalagi orang yang memiliki tidak mempunyai pekerjaan tetap sehingga tidak bisa menghasilkan uang dan kemungkinan besar juga pasien memikirkan tentang keadaan setelah operasi takut terjadi hal-hal yang membuat dia tambah cacat, sehingga dia selalu merasa cemas, dan selalu bertanya-tanya dalam dirinya apakah masih dapat bekerja setelah menjalani operasi atau tidak, karena belum mendapat jawaban yang jelas tentang dia tambah sehat setelah operasi atau tambah sakit, Sehingga menjadi pemicu meningkatnya rasa kecemasan pada pasien. Sedangkan pasien yang memliki pekerjaan tetap menunjukkan sebagaian kecil mengalami kecemasan Ringan hal ini di sebabkan karena pasien tidak terlalu memikirkan masalah penghasilannya, Karena dengan penghasilan sebelumnya dapat membiayai operasi dan kebutuhan keluarganya seperti yang berstatus pegawai negeri sipil.

\section{Analisis pengaruh pendidikan kesehatan terhadap tingkat kecemasan pasien praoperasi bedah mayor orthopedi}

Penelitian ini menunjukkan pendidikan kesehatan mampu mempengaruhi tingkat kecemasan pasien praoperasi bedah mayor. Pada responden kelompok intervensi secara umum menunjukkan adanya penurunan kecemasan setelah dilakukan intervensi dan mengalami peningkatan pendidikan kesehatan ringan yang berarti baik. Tingkat kecemasan berdasarkan analisis diketahui bahwa responden penelitian 
pada kelompok intervensi sebelum diberikan intervensi mempunyai tingkat kecemasan yang hampir seluruhnya mengalami kecemasan berat, setelah dilakukan intervensi terjadi penurunan tingkat kecemasan pada seluruh responden ditunjukkan dengan skor tingkat kecemasan yang menurun, sama halnya sebelum pada kelompok kontrol pertanyaan yang menunjukkan skor kecemasan berat, sedangkan setelah dilakukan kontrol terjadi perubahan yang tidak signifikan ada yang mengalami penurunan kecemasan.

Hasil observasi dan wawancara peneliti dengan pasien ditemukan tandatanda kecemasan seperti pasien mengalami tekanan darah meningkat, nadi meningkat, pernapasan meningkat, suhu meningkat, gelisah, takut dan mengalami penurunan konsentrasi pada saat peneliti menjelaskan prosedur penelitian. Kecemasan yang dialami responden seperti terjadi penundaan operasi teralu lama, takut operasi gagal, perasaan takut dengan kondisi ruangan bedah karena baginya asing, takut tidak bisa beraktivitas kembali, dan melihat pasien yang sudah dilakukan operasi di dalam satu ruangan. Sedangkan hasil observasi dan wawancara peneliti dengan pasien ditemukan pada dukungan keluarga yang sering meninggalkan pasien di ruang ketika perlu dukungan keluarga tidak ada ditempat dengan alasan berbagai macam, terkadang ada keluarga yang cuek terhadap keluarganya apabila keluarga perlu dukungan keluarga malah dimarahi, terkadang pasien di rawat oleh asisten rumah tangga dengan alasan keluarga sibuk bekerja dan urusan lain. Dari penelitian ini didapatkan bahwa nilai $p$ tingkat kecemasan pada kelompok intervensi 0,001 dan nilai $p$ dukungan keluarga 0,001 $(\mathrm{p}<0,05)$ dapat disimpulkan dari hasil penelitian ini membuktikan bahwa ada pengaruh pendidikan kesehatan terhadap tingkat kecemasan pasien praoperasi bedah mayor orthopedi di RSUD Dr. Soedarso Pontianak. sehingga ho ditolak dan ha diterima.

Hasil penelitian diatas pengaruh pendidikan kesehatan terhadap tingkat kecemasan pasien praoperasi bedah mayor orthopedi sejalan dengan penelitian Wijayanto (2014) dengan 32 responden yang terdiri dari 16 kelompok intervensi dan kelompok kontrol pada pasien praoperasi yang diberikan pemberian pendidikan kesehatan terstruktur $\mathrm{m}$ salah satu tindakan perawat untuk menurunkan kecemasan pada pasien preoperasi yang akan menjalani operasi, pasien yang akan menjalani pembedahan biasanya tidak tahu tentang prosedur pembedahan dan perawatan pascaoperasi. Kecemasan yang terjadi pada pasien praoperasi bervariasi dari ringan sampai berat, perawat perlu mengkaji psikologis pasien yang akan menjalani pembedahan. Hasil penelitian didapatkan bahwa ada pengaruh pendidikan kesehatan terstruktur terhadap kecemasan pada pasien preoperatif elektif mayor sebelum dan sesudah pada kelompok intervensi dengan $\mathrm{p}$ value $0,000<\alpha(0,05)$, sedangkan pada kelompok kontrol tidak ada pengaruh pendidikan kesehatan terhadap kecemasan pada pasien preoperatif elektif mayor.

Penelitian Romadoni (2016) terdapat 54 responden didapatkan hasil yang mengalami kecemasan ringan 28 responden dengan persentase $51,9 \%$, kecemasan sedang14 responden dengan persentase $25,9 \%$, dan kecemasan berat 12 responden dengan persentase $22,2 \%$, sedangkan hasil dukungan keluarga baik 34 responden dengan persentase $63 \%$ dan dukungan keluarga kurang baik 20 responden dengan persentase $34 \%$ didapatkan bahwa dari hasil analisa bivariat diperoleh nilai p-value sebesar 0.002 yang berarti terdapat hubungan antara dukungan keluarga dengan tingkat kecemasan pasien pre operasi 
mayor. dikarenakan bahwa setiap individu yang sedang mengalami kesulitan atau tekanan akan membutuhkan dukungan dari orang terdekat, untuk memberikan semangat, motivasi dan perhatian yang lebih terhadap keluarga yang sedang mengalami tekanan.

Berdasarkan penelitian Nisa (2018) dengan 167 responden bertolak belakang dengan penelitian saya didapatkan hasil bahwa dukungan keluarga pasien baik yang mengalami ansietas sedang sebanyak $106(94,6 \%)$ dan ansietas berat sebanyak $6(5,4 \%)$. Dukungan keluarga meliputi sikap, tindakan dan penerimaan keluarga terhadap penderita sakit, Salah satu peran dan fungsi keluarga yaitu memberikan fungsi afektif untuk pemenuhan kebutuhan psikososial anggota keluarganya dalam memberikan kasih sayang.

\section{SIMPULAN DAN SARAN}

\section{Simpulan}

Berdasarkan penelitian yang sudah dilakukan peneliti tentang pengaruh pendidikan kesehatan terhadap tingkat kecemasan pasien praoperasi bedah mayor orthopedi di RSUD Dr. Soedarso Pontianak, dapat disimpulkan adalah karakteristik responden usia pada kelompok intervensi dalam rentang usia dewasa akhir yaitu (36-45 tahun), kategori pendidikan responden pada kelompok intervensi hampir setengahnya berpendidikan sekolah dasar, kategori pekerjaan rata-rata bekerja sedangkan pada kelompok kontrol rentang usia pada lansia awal (26-35 tahun) jenis kelamin laki-laki, pendidikan responden pada kelompok kontrol sebagian besar berpendidikan SMA dan kategori pekerjaan responden pada kelompok kontrol sebagian besar bekerja, tingkat kecemasan pada kelompok intervensi, sebelum dilakukan intervensi sebagian besar mengalami kecemasan berat dengan presentase dan setelah dilakukan intervensi mengalami penurunan kecemasan sedang Sama hal dengan kelompok perlakuan pada kelompok kontrol sebagian besar responden mengalami kecemasan berat dan setelah dilakukan kontrol ada yang masih mengalmi kecemasan berat, dan Terdapat pengaruh pendidikan kesehatan terhadap tingkat kecemasan pasien praoperasi bedah mayor orthopedi di RSUD Soedarso Pontianak dengan hasil 0,001 dengan $p<0,05$

\section{Saran}

Saran Teoritis

Hasil penelitian ini diharapkan dapat meningkatkan perbaikan metode dengan memanfaatkan dukungan keluarga dan menggunakan intervensi. Hasil penelitian ini juga dapat dijadikan sebagai bahan atau sumber data bagi peneliti selanjutnya dan bahan pertimbangan bagi yang berkepentingan untuk melanjutkan penelitian terutama yang lebih menitikberatkan terkait pentingnya mengatasi kecemasan praoperasi bedah mayor orthopedi.

\section{Saran Praktis}

Bagi Keperawatan

Dalam ilmu keperawatan, penelitian ini diharapkan dapat memberikan tambahan tindakan keperawatan yang dapat dilakukan oleh perawat secara mandiri, khususnya pada keperawatan medikal bedah dengan penyuluhan kesehatan yang berkaitan dengan dukungan keluarga pada pasien praoperasi orthopedi.

Bagi lahan Penelitian

Hasil penelitian ini diharapkan dapat membantu dalam menangani pasien yang mengalami kecemasan praoperasi yang terjadi di RSUD Dr Soedarso dan sebagian besar responden terbanyak pada penelitian ini laki-laki dibandingkan perempuan sehingga direkomendasikan untuk peneliti selanjutnya untuk lebih memfokuskan karakteristik univariat jenis kelamin. 
Bagi Responden

Hasil penelitian ini diharapkan bahwa keluarga mempunyai peranan besar terhadap pasien yang mau melakukan operasi sehingga perlu didorong untuk diberi dukungan

\section{. KEPUSTAKAAN}

1. Asmadi. (2009). Teknik Prosedural Keperawatan: Konsep dan Aplikasi Kebutuhan Dasar Klien. Jakarta: Salemba Medika.

2. Anggraeni, R. (2018). Pengaruh Penyuluhan Manfaat Mobilisasi Dini Terhadap Pelaksanaan Mobilisasi Dini Pada Pasien Pasca Pembedahan Laparotomi. Jurnal Ilmiah Indonesia, 3(2), 107-121.

3. Barus, M., Simanullang, M. S., \& Gea, E. C. (2018). Pengaruh Progresif Muscle Relaxation Terhadap Tingkat Kecemasan Pre Operasi Di Rumah Sakit Santa Elisabeth Medan Tahun 2018. Jurnal Mutiara Ners, 1(2), 98-108.

4. Dharma, K. K. (2015). Metodologi Penelitian Keperawatan: Panduan Melaksanakan dan Menerapkan Hasil Penelitian. Jakarta: Trans Infomedi.

5. Firdaus, M. F. (2014). Uji Validasi Konstruksi dan Realibilitas Instrumen The Amsterdam Preoperative and Information Scale (APAIS) Versi Bahasa Indonesia. Tesis. tidak dipublikasikan.

6. Gangka, Y., Kadir, A., \& Semana, A. (2013). Faktor yang Berhubungan Dengantingkat Kecemasan Pasien Preoperasi Bedah Mayor Digestifdi Rsup Dr Wahidin Sudirohusodo Makasar. volume 2 Nomor 3 ISSN : 23021721, 1-8.
7. Kemenkes RI. (2017). Survei Demografi dan Kesehatan Indonesia. Jakarta: Kemenkes RI.

8. Nisa, R., PH, L., \& Arisdiani, T. (2018, November). Hubungan Dukungan Keluarga Dengan Tingkat Ansietas Pasien Pre Operasi Mayor. Jurnal Keperawatan Jiwa, Volume 6(2), 116-120.

9. Notoatmodjo, S. (2015). Metodelogi penelitian kesehatan. Jakarta: Renika Cipta.

10. Nursalam. (2017). Metodelogi Penelitian Ilmu Keperawatan Pendekatan Praktik. Jakarta: Salemba Medika.

11. Rahmayati, E., Silaban, R. N., \& Fatona, S. (2018). Pengaruh Dukungan Spritual terhadap Tingkat Kecemasan pada Pasien Pre-Operasi. Jurnal Kesehatan, 9(1), 138-142.

12. Romadoni, S., \& Putri, M. (2018). Tingkat Kecemasan dengan Tanda Vital Pasien di Ruang Intensif Rumah Sakit . STIKes Muhammadiyah, 271-276.

13. Widyastuti, Y. (2013). Efektivitas Aromaterapi Lavender Dalam Menurunkan Nyeri dan Kecemasan Pada Pasien Pre Operasi Fraktur Femur Di Rs Ortopedi Prof. Dr.R Soeharso Surakarta. Prosiding Konferensi Nasional PPNI Jawa Tengah 2013. 92-94.

14. WHO (2013). World Health Organization.

15. Wijayanto, Tri \& Abdullah, Farih . (2014). Pengaruh Pendidikan Kesehatan Terstruktur terhaap Tingkat Kecemasan pada pasien Preoperasi Elektif Mayor. 1-10. 

